Jurnal Laut Khatulistiwa, Vol. 4 No. 1 (Febuari, 2021), Hal. 29-39.

ISSN : 2614-6142 (Printed), 2614-8005 (Online)

http://jurnal.untan.ac.id/index.php/lk

JURNAL LAUT

KHATULISTIWA

\title{
Struktur Komunitas Mikroalga Epifit Pada Padina dan Caulerpa di Perairan Pulau Kabung Kalimantan Barat
}

\section{Community Structure of Epiphytic Microalgae on Padina and Caulerpa in the Waters of Kabung Island West Kalimantan}

\author{
Maulana Hidayat ${ }^{*}$, Warsidah ${ }^{2}$, Ikha Safitri ${ }^{2}$ \\ ${ }^{1}$ Program Studi Ilmu Kelautan, FMIPA Universitas Tanjungpura, Pontianak, Indonesia \\ ${ }^{2}$ Laboratorium Ilmu Kelautan, FMIPA Universitas Tanjungpura, Pontianak, Indonesia \\ *E-mail : maulanahidayat600@gmail.com
}

Received : 27 Januari 2021; Accepted: 21 Febuari 2021

Published: 28 February (C) Author(s) 2021. This article is open access

\begin{abstract}
This study aims to determine the structure of the epiphytic microalgae communities in Padina and Caulerpa, the quality of the aquatic environment and the correlation of the density of epiphytic microalgae with the parameters of the aquatic environment in Kabung Island West Kalimantan. This research was conducted in October 2019 using a survey method and the determination of the sampling station by purposive sampling which consists of three stations based on the environmental baseline. Station I is the boat dock, Station II is citizen activity and Station III is without citizen activity. Structure of epiphytic microalgae communities in Padina and Caulerpa the waterway Kabung Island consisted of 5 divisions, 7 classes, 45 orders, 62 families and 76 genera. The highest density of epiphytic microalgae in the surface watersof Kabung Islandis stasion III with values (4873 ind $/ 5 \mathrm{~g}$ and 80,28\%) in Padina and the lowest density is stasion I (2653 ind/5g and 63,24\%) in Caulerpa. The dominant genera most Amphora, Nitzchia, Pinnularia, Synedra, Chlamydomonas and Botryodiopsis. The range diversity index $\left(H^{\prime}\right)(3,58-3,71)$, uniformity index $(E)(0,84-0,89)$, dominance index (C) $(0,03-0,04))$ and sorensen similarity index $(89,70-94,28 \%)$. The environmental parameters of Kabung Island waters which have a perfect correlation with the density of epiphytic microalgae are temperature, DO, salinity, conductivity, currents and nitrates with a value of 1 to -1, whereas depth, phosphate and $p H$ tended not to show a significant.
\end{abstract}

Keywords : Community Structure, Microalgae, Purposive Sampling, Density, Index, Correlation.

\begin{abstract}
Abstrak
Penelitian ini bertujuan untuk mengetahui struktur komunitas mikroalga epifit pada Padina dan Caulerpa, kualitas lingkungan perairan dan korelasi kepadatan mikroalga epifit dengan parameter lingkungan perairan di Pulau Kabung Kalimantan Barat. Penelitian ini telah dilaksanakan pada bulan Oktober 2019 dengan menggunakan metode survei dan penentuan stasiun pengambilan sampel secara purposive sampling yang terdiri dari tiga stasiun berdasarkan rona lingkungan. Stasiun I terdapat dermaga kapal, stasiun II terdapat aktivitas penduduk dan stasiun III tanpa aktivitas penduduk. Struktur komunitas mikroalga epifit pada Padina dan Caulerpa di perairan Pulau Kabung terdiri dari 5 divisi, 7 kelas, 45 ordo, 62 famili dan 76 genus. Kepadatan tertinggi mikroalga epifit di Perairan Pulau Kabung terdapat di stasiun III dengan nilai (4873 ind/5g) pada Padina dan kepadatan terendah yaitu stasiun I (2653 ind/5g) pada Caulerpa. Genus yang paling mendominasi adalah Amphora, Nitzchia, Pinnularia, Synedra, Chlamydomonas dan Botrydiopsis. Kisaran indeks keanekaragaman $\left(\mathrm{H}^{\prime}\right)$ berkisar antara $(3,58-3,71)$, indeks keseragaman (E) (0,84-0,89), indeks dominansi (C) $(0,03-0,04)$ dan indeks similaritas Sorensen $(89,70-94,28 \%)$. Parameter lingkungan perairan Pulau Kabung yang berkolerasi sempurna terhadap kepadatan mikroalga epifit adalah suhu, DO, salinitas, konduktivitas, arus dan nitrat dengan nilai 1 sampai -1, sedangkan kedalaman, fosfat dan $\mathrm{pH}$ cenderung tidak menunjukkan korelasi yang signifikan.
\end{abstract}

Kata kunci : Struktur Komunitas, Mikroalga, Purposive Sampling, Kepadatan, Indeks, Korelasi 
Jurnal Laut Khatulistiwa, Vol. 4. No. 1 (Febuari, 2021), Hal. 29-39.

\section{Pendahuluan}

Perairan Pulau Kabung termasuk wilayah Kabupaten Bengkayang, Kalimantan Barat yang memiliki luas 1.500 ha dan memiliki potensi keanekaragaman hayati laut seperti rumput laut (makroalga) (BPS Kalimantan Barat, 2010; Marianingsih et al., 2013). Berdasarkan hasil survei penelitian di Perairan Pulau Kabung menunjukan bahwa makroalga Padina dan Caulerpa merupakan jenis yang banyak ditemukan di semua stasiun. Padina dan Caulerpa merupakan makroalga yang terdistribusi melimpah di perairan tropis, subtropis dan hidup di zona intertidal (Wai and Htun,2013; Meinesz and Boudouresque, 1996; Pribadi et al., 2017). Secara ekologi makroalga memiliki fungsi sebagai tempat pemijahan (spawning grounds), tempat asuhan (nursery grounds), tempat mencari makan (feeding grounds) dan sebagai tempat hidup mikroorganisme salah satunya mikroalga epifit (Handayani and Kadi, 2007; Al-Harbi, 2017a; Al-Harbi, 2017b).

Mikroalga epifit merupakan mikroorganisme yang hidup melekat pada tumbuhan di perairan dan termasuk dalam kelompok alga perifiton (Hendrawati et al., 2018; Putri et al., 2017) serta memiliki peran dalam meningkatkan produksi primer di perairan (Widjaja, 2009). Kepadatan mikroalga epifit memiliki peran sebagai bioindikator pencemaran perairan karena dapat merespons kondisi pertumbuhan lingkungan perairan (Kawaroe et al., 2010; Hadiyanto dan Azam, 2012; Awal et al., 2014). Tujuan dari penelitian ini untuk menganalisis struktur komunitas mikroalga epifit pada Padina dan Caulerpa di Perairan Pulau Kabung.

\section{Metodologi Penelitian}

\subsection{Waktu dan Lokasi Penelitian}

Penelitian dilakukan pada bulan Oktober 2019 di Perairan Pulau Kabung, Kalimantan Barat (Gambar 1). Penelitian dilakukan dengan metode survei langsung di lapangan untuk mendapatkan data primer mengenai keberadaan makroalga Padina dan Caulerpa dengan penentuan stasiun pengamatan secara purposive sampling berdasarkan rona lingkungan (Tarigas et al., 2020). Lokasi pengambilan sampel Padina dan Caulerpa terdiri dari 3 stasiun. Stasiun I daerah dermaga kapal dengan titik koordinat (N 0049'23.41"E $108^{\circ} 47^{\prime} 08.93^{\prime \prime)}$, stasiun II berada di rona pemukiman penduduk dengan titik koordinat (N 0049'14.30"E $108^{\circ} 46^{\prime} 54.62^{\prime \prime}$ ) dan stasiun III berada di rona tanpa pemukiman penduduk dengan titik koordinat ( $\mathrm{N} \mathrm{00} 49^{\prime} 18.67^{\prime \prime} \mathrm{E}$ $\left.108^{\circ} 46^{\prime} 35.12 "\right)$. Pengambilan sampel makroalga dilakukan pada daerah yang dipengaruhi oleh pasang surut dan pertama kali ditemukannya makroalga (Din et al., 2015)

\subsection{Pemisahan Mikroalga Epifit}

Makroalga Padina dan Caulerpa ditimbang sebanyak 5 gram dengan 2 kali pengulangan. Makroalga yang sudah ditimbang selanjutnya dikerik pada seluruh bagian thallus dengan menggunakan cutter. Tujuan pengirikan adalah untuk memisahkan mikroalga epifit yang menempel pada thallus (Lestari et al., 2020; Tarigas et al., 2020).

Mikroalga epifit yang didapatkan kemudian dimasukkan ke dalam botol sampel ukuran $20 \mathrm{~mL}$ dan ditambahkan air laut steril untuk mendapatkan mikroalga epifit yang terkonsentrat. Selanjutnya ditambahkan formalin $4 \%$ sebanyak 3 tetes dengan tujuan pengawetan. Pengamatan mikroalga dilakukan dengan menggunakan mikroskop binokuler dengan pembesaran 10x10 hingga 40x10 (Herlina et al., 2018; Yusuf, 2018).

\subsection{Pengukuran Parameter Perairan}

Pengukuran parameter lingkungan perairan dilakukan dengan dua cara yaitu in situ dan ex situ. Parameter yang diukur secara in situ meliputi salinitas, kecepatan arus, suhu, kedalaman, DO (Dissolved Oxygen), pH (Potensial of Hydrogen) dan konduktivitas, sedangkan nitrat dan fosfat dilakukan secara ex situ dan dianalisis di Balai Riset dan Standarisasi Industri Pontianak (BARISTAN). Metode pengambilan sampel air laut untuk uji nitrat dan fosfat mengacu pada (SNI 6964.8: 2015) tentang Metode Pengambilan Contoh Uji Air Laut.

\subsection{Analisis Data}

Nilai Kepadatan mikroalga epifit dapat dihitung menggunakan rumus modifikasi Eaton (1995):

$\mathrm{K}=\frac{\mathrm{Vr}}{\mathrm{Vo}} \times \frac{1}{\mathrm{~W}} \times \mathrm{n}$ 
Jurnal Laut Khatulistiwa, Vol. 4. No. 1 (Febuari, 2021), Hal. 29-39.

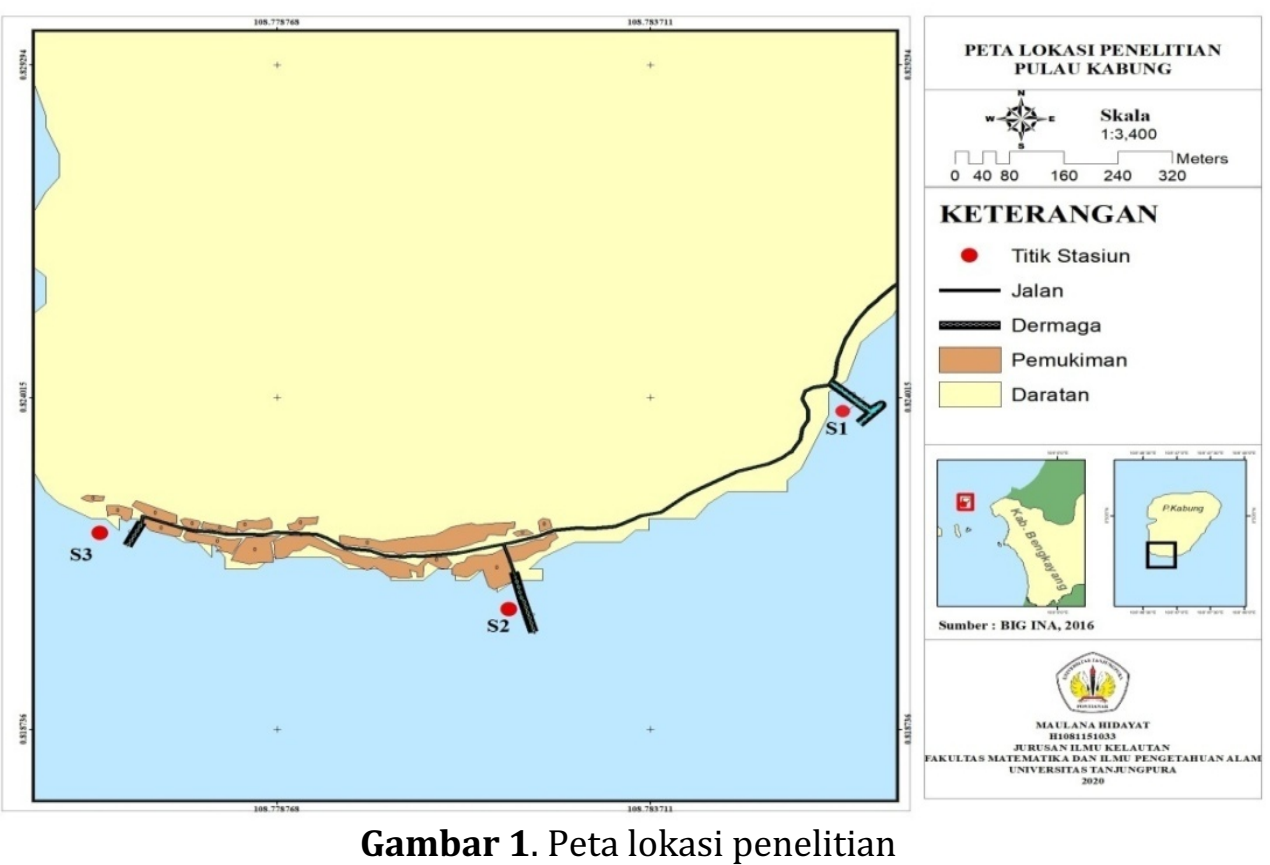

Dimana K merupakan jumlah kepadatan epifit (ind/g berat basah makroalga), $\mathrm{Vr}$ adalah volume konsentrat dalam botol sampel (20 $\mathrm{mL})$, Vo adalah volume satuan tetes air sampel $(0,05 \mathrm{~mL}), \mathrm{W}$ adalah berat basah makroalga (5 gram) dan $\mathrm{n}$ adalah jumlah mikroalga epifit yang tercacah (ind).

Perhitungan Kepadatan Relatif mikroalga epifit menggunakan rumus (APHA, 2000):

$\mathrm{KR}=\frac{\mathrm{K} \text { suatu jenis }}{\mathrm{K} \text { semua jenis }} \times 100$

Dimana KR merupakan kepadatan relatif (\%) dan $\mathrm{K}$ adalah kepadatan mikroalga epifit.

Perhitungan Indeks Keanekaragaman dihitung dengan persamaan Shannon-Wienner berdasarkan rumus (Washington, 1984):

$\mathrm{H}^{\prime}=-\sum P i \ln P i$

Dimana $\mathrm{H}^{\prime}$ adalah Indeks Keanekaragaman jenis Shannon-Wienner, $\mathrm{Pi}$ adalah ni/N (proporsi jenis ke-i), ni adalah jumlaha individu jenis ke- $i$ dan $\mathrm{N}$ adalah total kepadatan (ind/5g). Menurut Krebs (1989) apabila $\mathrm{H}^{\prime}<1$ maka keanekargaman mikroalga epifit tergolong rendah, nilai $1<\mathrm{H}^{\prime}<3$ maka keanekaragaman mikroalga epifit tergolong sedang, nilai $\mathrm{H}^{\prime}>3$ maka keanekaragaman mikroalga epifit tergolong tinggi.
Perhitungan Indeks Keseragaman dapat dihitung berdasarkan rumus (Magurran, 1988):

$E=\frac{H^{\prime}}{\ln S}$

Dimana E merupakan Indeks Keseragaman Evennes, $\mathrm{H}^{\prime}$ adalah indeks keanekaragaman Shannon-Wiener, $\mathrm{H}^{\prime}$ max adalah $\ln \mathrm{S}$ dan $\mathrm{S}$ adalah banyaknya genus yang ditemukan pada setiap stasiun. Menurut Odum (1993) indeks keseragaman dari suatu populasi berkisar antara 0-1, nilai E mendekati 0 menunjukkan bahwa persebaran individu antar jenis tidak seragam dan cenderung tidak merata dan apabila nilai E mendekati 1 maka sebaran individu antar jenis seragam.

Perhitungan Indeks Dominansi ditentukan dengan menggunakan rumus dominansi Simpson (Washington, 1984):

$\mathrm{C}=\sum(\mathrm{ni} / \mathrm{N})^{2}$

Dimana C adalah Indeks Dominansi Simpson, ni adalah jumlah individu setiap spesies i dan $\mathrm{N}$ adalah jumlah total individu. Indeks dominansi memiliki kriteria dimana nilai dominansi $<0,50$ maka dominansi tergolong rendah, apabila $0,50<\mathrm{C}<0,75$ maka dominansi tergolong sedang jika $\mathrm{C}>0,75$ maka dominansi tergolong tinggi. 
Jurnal Laut Khatulistiwa, Vol. 4. No. 1 (Febuari, 2021), Hal. 29-39.

Perhitungan Indeks similaritas Sorensen digunakan untuk melihat kemiripan spesies mikroalga epifit antar stasiun dengan rumus (Krebs, 1989):

$I S=\frac{2 c}{a+b}$

Dimana a adalah jumlah spesies atau genus mikroalga pada stasiun a, b adalah jumlah spesies atau genus mikroalga pada stasiun $b$ dan c adalah jumlah spesies atau genus yang sama pada stasiun a dan b. Nilai indeks similaritas Sorensen mencapai $75-100 \%$ artinya sangat mirip, $50-75 \%$ mirip, $25-50 \%$ artinya tidak mirip dan apabila nilai $<25 \%$ artinya sangat tidak mirip.

Untuk mengetahui hubungan kepadatan mikroalga epifit dengan parameter lingkungan dapat dilakukan uji korelasi Spearmean dengan bantuan software SPSS versi 25 .

\section{Hasil dan Pembahasan}

\subsection{Struktur Komunitas Mikroalga Epifit pada Padina dan Caulerpa di Perairan Pulau Kabung.}

Hasil identifikasi mikroalga epifit yang ditemukan pada Padina dan Caulerpa di perairan Pulau Kabung, Kalimantan Barat terdiri dari 5 divisi, 7 kelas, 45 ordo, 62 famili dan 76 genus (Gambar 2). Dari total genus yang teridentifikasi 43 genus termasuk dalam kelas Bacillariophyceae, 13 genus Chlorophyceae, 1 genus Coleochaetophyceae, 10 genus Cyanophyceae, 5 kelas Dynophyceae, Trebouxiophyceae 2 genus dan Ulvophyceae 2 genus.

Kelas Bacillariophyceae merupakan kelas yang sangat dominan ditemukan di kedua makroalga. Pada stasiun I kelas Bacillariophyceae ditemukan sebanyak 38 genus dengan persentase $77,45 \%$, stasiun II 41 genus $(78,77 \%)$ dan stasiun III 42 genus $(80,28 \%)$ pada Padina, sedangkan pada Caulerpa stasiun I ditemukan sebanyak 36 genus $(63,24 \%)$, stasiun II 37 genus $(63,3 \%)$ dan stasiun III 40 genus $(64,29 \%)$ (Gambar 3). Genus dari kelas Bacillariophyceae memiliki jumlah tertinggi pada stasiun III. Tingginya kelas Bacillariophyceae menunjukkan bahwa kelas Bacillariophyceae memiliki sifat kosmopolitan yang mampu beradaptasi dengan kondisi perubahan lingkungan perairan (Ismail, 2016; Utama et al., 2019). Hasil penelitian ini serupa dengan penelitian Lestari et al, (2020) di perairan Desa Sepempang, Kabupaten Natuna dimana kelas Bacillariophyceae memiliki persentase tertinggi mencapai 79,21\%.

Tingginya jumlah genus dari kelas Bacillariophyceae juga dapat dipengaruhi oleh ketersediaan nutrisi seperti nitrat dan fosfat yang terdapat di stasiun III. Menurut Arinardi et al, (1997) menyebutkan bahwa mikroalga dari kelas Bacillariophyceae banyak ditemukan di perairan laut dan estuari karena dapat memanfaatkan kadar zat hara lebih banyak untuk metabolisme. Menurut Lutfhiandra et al, (2018) konsentrasi nitrat dan fosfat yang tinggi di perairan dapat menstimulasi pertumbuhan dan mepengaruhi kepadatan kelas Bacillariophyceae. Kadar nitrat di satasiun III sebesar $(0,081 \mathrm{mg} / \mathrm{L})$ dan fosfat $(0,014 \mathrm{mg} / \mathrm{L})$.

Nitrat adalah bentuk nitrogen utama di perairan laut. Nitrat merupakan salah satu nutrisi yang penting dalam sintesa protein hewan dan tumbuhan. Nitrogen akan diserap oleh mikroalga dalam bentuk nitrat dan amonia $\left(\mathrm{NH}_{3}-\mathrm{N}\right)$. Kandungan nitrat disuatu perairan dapat dihasilkan dari limbah hasil ekskresi manusia dan hasil ekskresi biota akuatik dan limbah domestik. Menurut Vinneras et al, (2006) menyebutkan bahwa feses manusia mengandung senyawa nitrogen sebesar 20\%, sedangkan urine manusia mengandung 19\% nitrogen (Mara and Craincross, 1994). Berdasarakan KLH No 51 Tahun 2004 kadar nitrat yang normal di perairan laut adalah $(>0,008 \mathrm{mg} / \mathrm{L})$.

Fosfat merupakan salah satu senyawa anorganik yang dihasilkan oleh limbah domestik seperi feses, urine dan deterjen dimana senyawa tersebut dapat menjadi sumber energi untuk mikroalga epifit (Nurdiansyah et al., 2010). Feses dan urine pada manusia memiliki konsentrasi fosfat sebesar 20-65\% dan detergen merupakan bahan pembersih yang mengandung senyawa petrokimia atau surfaktan (fosfat) (Putri et al., 2014; Dhaktie et al., 2011). Kandungan fosfat yang tinggi akan mengakibatkan meningkatnya populasi mikroalga dari kelas Bacillariophyceae (Pello et al., 2014).

Kelas Chlorophyceae memiliki nilai tertinggi pada Padina dan Caulerpa di stasiun 
Jurnal Laut Khatulistiwa, Vol. 4. No. 1 (Febuari, 2021), Hal. 29-39.

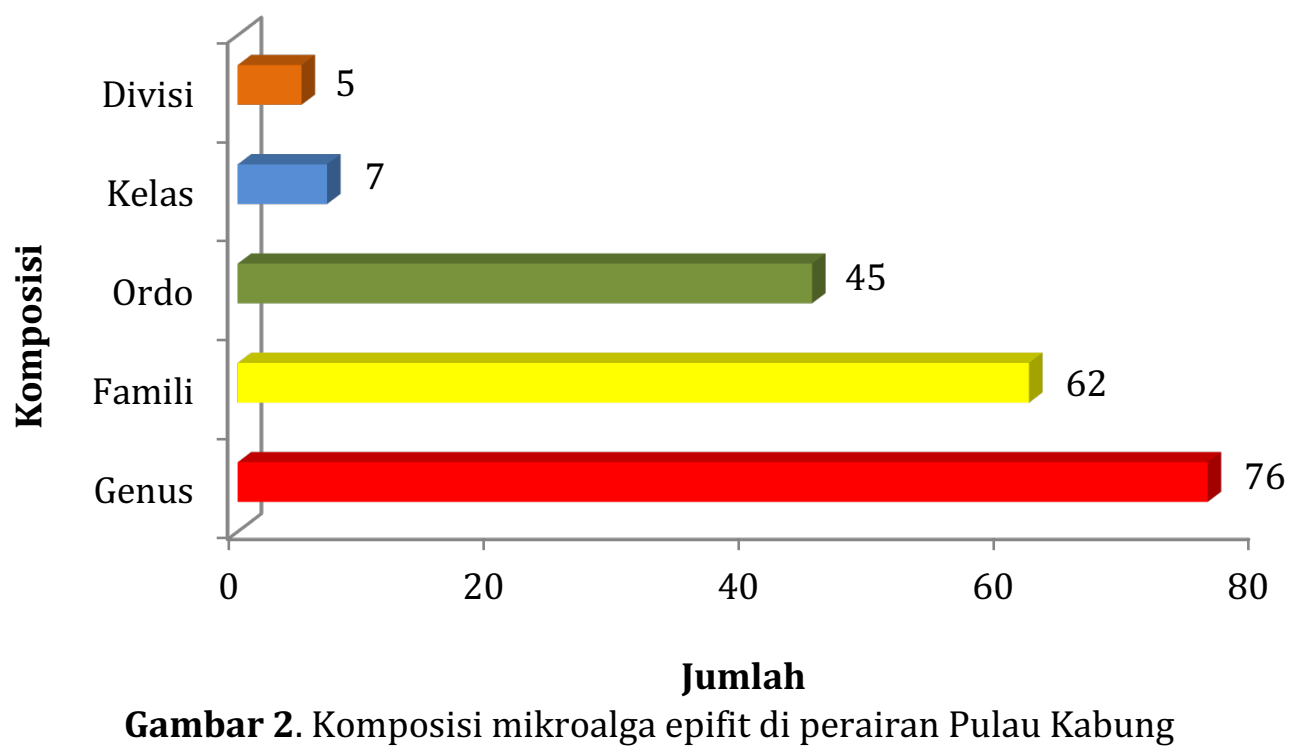

III. Persentase mikroalga epifit dari kelas Chlorophyceae sbesar 8,53\% pada Padina dan $25,24 \%$ pada Caulerpa (Gambar 3). Tingginya kepadatan Chlorophyceae di stasiun III disebabkan oleh salinitas yang rendah $(30,7$ ppt) dan kadar nitrat yang tinggi $(0,081 \mathrm{mg} / \mathrm{L})$. Menurut Cartensen et al, (2004), salinitas yang tinggi di suatu perairan akan merusak dan menghambat pertumbuhan mikroalga dari kelas Chlorophyceae.

Kelas Dinophyceae merupakan mikroalga yang banyak ditemukan di perairan Pulau Kabung Kalimantan Barat dengan persentase tertinggi sebesar $2,23 \%$ di stasiun I pada Padina dan 2,28\% di stasiun II pada Caulerpa (Gambar 3). Tingginya kepadatan kelas Dinophyceae dipengaruhi oleh meningkatnya nilai salinitas. Menurut Barokah et al, (2016) tingginya kepadatan Dinophyceae diakibatkan oleh tingginya salinitas di suatu perairan. Fenomena meningkatnya kepadatan kelas Dinophyceae akan mengakibatkan blooming algae sehingga fenomena tersebut akan mengganggu keseimbangan ekosistem perairan, dimana kelas Dinophyceae dapat menghasilkan toksin yang dapat menyebabkan kematian bagi biota akuatik (HarnandezBecerril et al., 2012; Nitajohan, 2008; Aprianti et al., 2015).

Kepadatan tertinggi mikroalga epifit di perairan Pulau Kabung didapatkan pada stasiun III sebanyak 4873 ind/5g untuk Padina dan kepadatan mikroalga epifit terendah pada stasiun I sebesar 2653 ind/5g untuk Caulerpa. Genus Amphora, Nitzchia dan Synedra merupakan mikoalga yang mendominasi pada Padina sedangkan genus Synedra dan Botryodiopsis mendominasi pada Caulerpa. Genus Amphora memiliki kepadatan tertinggi mencapai 268 ind/5g di stasiun I pada Padina dan 182 ind/5g di stasiun II pada Caulerpa. Perbedaan jumlah kepadatan dari genus Amphora diduga adanya perbedaan nilai dari setiap parameter lingkungan. genus Nitzchia memiliki kepadatan tertinggi sebesar 426 ind/5g di stasiun III pada Padina dan 168 ind/5g pada Caulerpa. Tingginya kepadatan genus Nitzchia dikarenakan karakteristiknya yang soliter dan mampu beradaptasi dengan lingkungan yang ekstrem. Perbedaan jumlah kepadatan mikroalga epifit pada Padina dan Caulerpa dikarenakan adanya perbedaan morfologi, fisiologi dan anatomi dari kedua makroalga. Secara morfologi Padina memiliki thallus yang lebar dan membentuk kipas yang rimbun dengan diameter $15 \mathrm{~cm}$, sedagkan Caulerpa memiliki thallus yang bulat dengan diameter 1-2 mm (Win et al., 2013; Pulukadang et al., 2013).

Nilai indeks keanekaragaman ( $\left.\mathrm{H}^{\prime}\right)$ mikroalga epifit pada Padina dan Caulerpa di perairan Pulau Kabung mendapatkan hasil yang sama dengan kisaran 3,58-3,71 dengan nilai tertinggi di dapatkan pada stasiun III dan nilai terendah didapatkan pada stasiun II. Nilai indeks keanekaragaman jenis menunjukkan bahwa mikroalga epifit pada Padina dan Caulerpa termasuk dalam kondisi tinggi (Tabel 1). 
Jurnal Laut Khatulistiwa, Vol. 4. No. 1 (Febuari, 2021), Hal. 29-39.
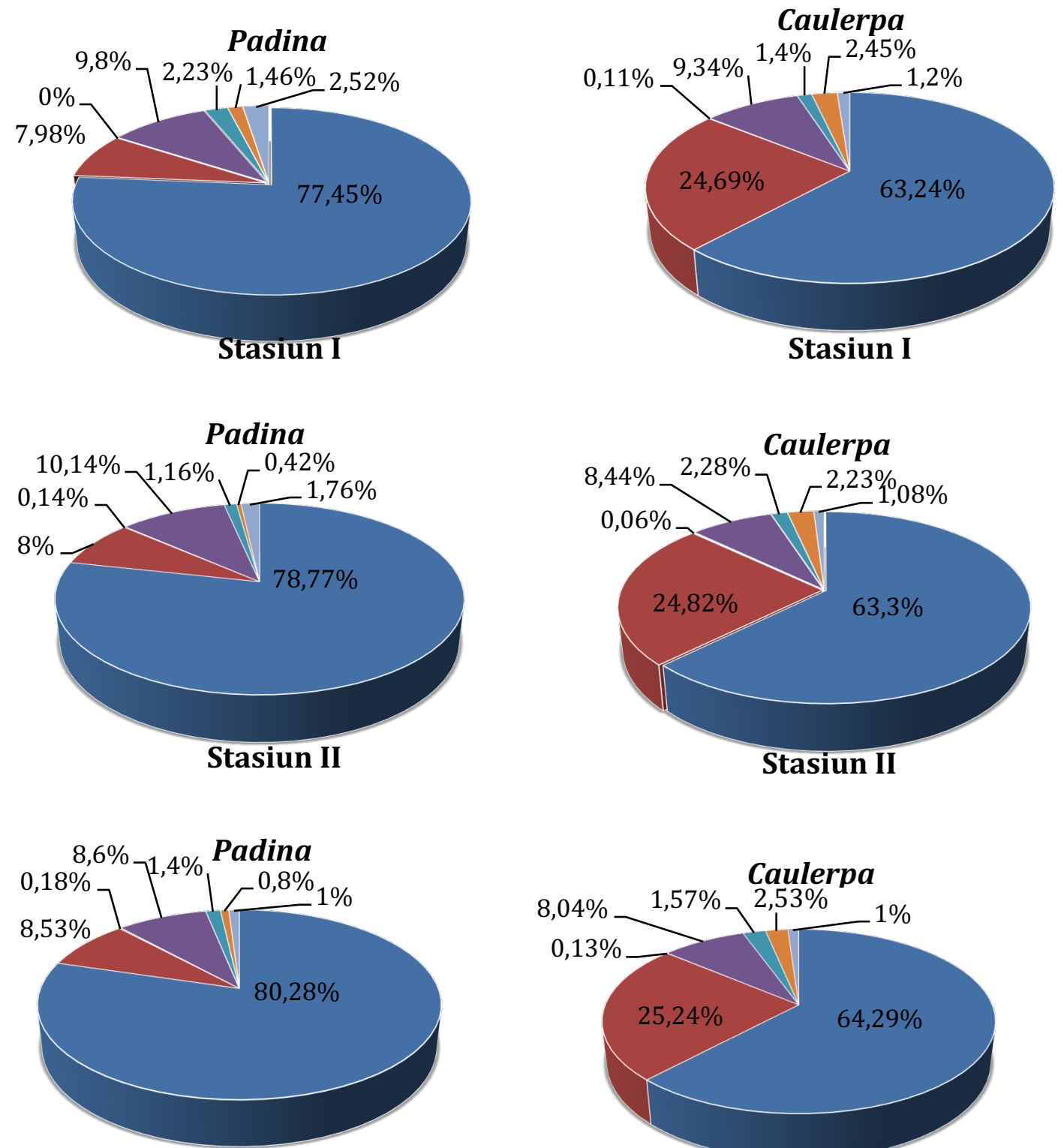

Stasiun III

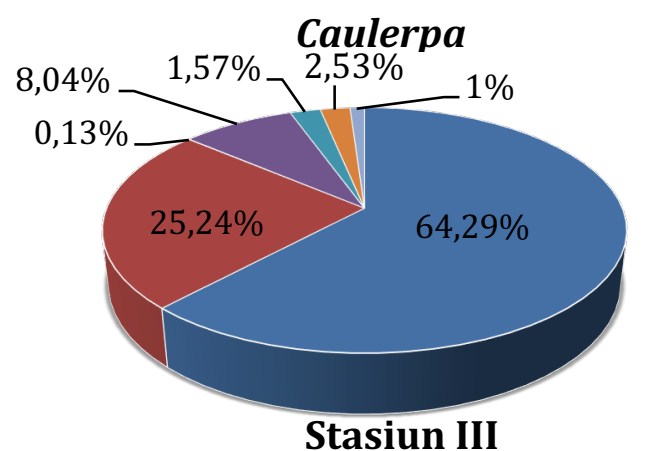

Gambar 3. Persentase mikroalga epifit berdasarkan kelas pada setiap stasiun

Nilai indeks keseragaman (E) jenis mikroalga epifit pada Padina dan Caulerpa diperairan Pulau Kabung mendapatkan nilai yang seragam (sama) dengan kisaran 0,840,89 (Tabel 1). Nilai indeks keseragaman tertinggi terdapat di stasiun I dan III pada Padina dan Caulerpa. Nilai keseragaman menunjukkan bahwa semakin tinggi nilai indeks keseragaman maka jumlah individu setiap genus tersebut sama dan tidak ada yang mendominansi.

Indeks dominansi (C) menunjukkan dominansi suatu jenis dalam suatu komunitas
(Odum, 1993). Nilai indeks dominansi mikroalga epifit pada Padina dan Caulerpa di perairan Pulau Kabung mendapat nilai yang rendah dengan kisaran 0,03-0,04 (Tabel 1). Hal tersebut menunjukkan bahwa tidak ada mikroalga epifit yang mendominasi secara absolut.

Nilai indeks similarits pada Padina di perairan Pulau Kabung berkisar antara 89,70\%94,28\%, sedangkan pada Caulerpa 91,17\%$92,95 \%$ (Tabel 2). Tingkat indeks similaritas tertinggi pada Padina dan Caulerpa yaitu antara stasiun II dan stasiun III. Berdasarkan kategori, stasiun II dan stasiun III memiliki tingkat 
Jurnal Laut Khatulistiwa, Vol. 4. No. 1 (Febuari, 2021), Hal. 29-39.

Tabel 1. Indeks keanekaragaman (H'), keseragaman (E) dan Dominansi (C)

\begin{tabular}{cccc}
\hline \multirow{2}{*}{ Stasiun } & \multicolumn{3}{c}{ Indeks Mikroalga Epifit pada Padina dan Caulerpa } \\
\cline { 2 - 4 } & $\left(\mathrm{H}^{\prime}\right)$ & $(\mathrm{E})$ & $(\mathrm{C})$ \\
\hline I & 3,60 & 0,85 & 0,03 \\
II & 3,58 & 0,84 & 0,03 \\
III & 3,71 & 0,89 & 0,04 \\
\hline
\end{tabular}

Tabel 2. Indeks Similaritas Sorensen Mikroalga Epifit pada Padina dan Caulerpa

\begin{tabular}{cccc}
\hline \multicolumn{5}{c}{ Indeks Similaritas Sorensen Padina } \\
\hline \multirow{2}{*}{ Stasiun } & \multicolumn{3}{c}{ Stasiun } \\
\cline { 2 - 4 } & I & II & III \\
\hline I & - & $91,17 \%$ & $91,42 \%$ \\
II & - & - & $92,95 \%$ \\
III & - & - & - \\
\hline \multicolumn{5}{c}{ Stasiun } & \multicolumn{4}{c}{ Indeks Similaritas Sorensen Caulerpa } \\
\cline { 2 - 4 } I & I & Stasiun & II \\
II & - & $90,90 \%$ & $89,70 \%$ \\
III & - & - & $94,28 \%$ \\
\hline
\end{tabular}

similaritas sangat mirip. Hal tersebut diduga letak antar stasiun II dan III saling berdekatan. Menurut Herlina et al, (2018) jika nilai indeks similaritas yang sama antar stasiun, maka jarak stasiun tersebut saling berdekatan sehingga massa air dan nutrisi yang diperoleh dari limbah domestik atau limbah lainnya saling bercampur.

Percampuran nutrisi yang terkandung di perairan diduga dapat mempengaruhi kesamaan spesies antar stasiun (Barus, 2000).

\subsection{Hubungan Kepadatan Mikroalga dengan Parameter Lingkungan Perairan}

Pengukuran parameter lingkungan seperti suhu, salinitas, $\mathrm{pH}$, kedalaman, kecepatan arus, konduktivitas, nitrat dan fosfat menunjukkan hasil yang optimal bagi pertumbuhan mikroalga epifit (Safitri and Putri, 2013; Aramita et al., 2015). Hasil analisis pengukuran parameter lingkungan perairan di Pulau Kabung dapat lihat pada (Tabel 3)

Berdasarkan uji korelasi Spearmean menunjukkan bahwa kepadatan mikroalga epifit memiliki hubungan yang nyata dengan parameter lingkungan seperti suhu, DO, salinitas, konduktivitas, arus dan nitrat dimana hubungan yang terjadi tergolong sempurna dengan nilai 1 sampai -1 (Tabel 4). Menurut Pitipaldi et al., (2017) apabila hasil korelasi mendapatkan nilai 1 maka hubungan antar variabel tergolong positif sempurna, dimana hubungan antar variabel searah, sebaliknya jika korelasi mendapatkan nilai -1 maka hubungan antar variabel tergolong negatif sempurna dimana hubungan antar variabel tidak searah.

Berdasarkan hasil yang diperoleh dari uji korelasi Spearmean menunjukkan bahwa parameter lingkungan perairan Pulau Kabung yang berkorelasi positif dengan kepadatan mikroalga epifit adalah suhu, D0, arus dan nitrat dengan nilai 1 (Tabel 4). Hal tersebut menunjukkan bahwa tingginya kepadatan mikroalga epifit maka searah dengan tingginya nilai suhu, DO, arus dan nitrat.

Parameter lingkungan yang berkorelasi negatif dengan kepadatan mikroalga epifit pada Padina dan Caulerpa di perairan Pulau Kabung adalah salinitas kan konduktivitas dengan nilai -1 hasil tersebut tergolong negatif sempurna dimana hubungan antar variabel tidak searah (berlawanan) (Tabel 4). Hal tersebut menunjukkan bahwa semakin tinggi nilai 
Jurnal Laut Khatulistiwa, Vol. 4. No. 1 (Febuari, 2021), Hal. 29-39.

Tabel 3. Parameter Lingkungan perairan di Pulau Kabung

\begin{tabular}{|c|c|c|c|c|c|}
\hline \multirow{2}{*}{ No } & \multirow{2}{*}{ Parameter } & \multicolumn{3}{|c|}{ Stasiun Penelitian } & \multirow{2}{*}{ Literatur } \\
\hline & & I & II & III & \\
\hline 1 & Suhu (C) & 29,8 & 29,9 & 30,5 & $\begin{array}{c}\text { Alami (KLH, No } 51 \text { Tahun } \\
\text { 2004) }\end{array}$ \\
\hline 2 & DO (mg/L) & 7,35 & 8,15 & 9,5 & $\begin{array}{c}>5 \mathrm{mg} / \mathrm{L} \text { (KLH, No } 51 \text { Tahun } \\
\text { 2004) }\end{array}$ \\
\hline 3 & $\mathrm{pH}$ & 8,62 & 8,62 & 8,62 & 7,6-8,3 (Safitri and Putri 2013) \\
\hline 4 & Salinitas (ppt) & 31,1 & 30,9 & 30,7 & $\begin{array}{l}\text { 25-35 ppt (Lingnot et al., } \\
\text { 2000) }\end{array}$ \\
\hline 5 & Konduktivitas $(\mu \mathrm{S} / \mathrm{cm})$ & 46,3 & 46,2 & 45,8 & - \\
\hline 6 & Kedalaman (m) & 1,6 & 1,3 & 1,8 & - \\
\hline 7 & Kecepatan arus (m/s) & 0,04 & 0,055 & 0,07 & $\begin{array}{c}0,02-0,2 \mathrm{~m} / \mathrm{s} \text { (Aramita et al., } \\
2015 \text { ) }\end{array}$ \\
\hline 8 & Nitrat (mg/L) & 0,043 & 0,058 & 0,081 & $\begin{array}{l}>0,008 \text { (KLH, No } 51 \text { Tahun } \\
\text { 2004) }\end{array}$ \\
\hline 9 & Fosfat (mg/L) & 0,008 & 0,004 & 0,014 & $\begin{array}{c}\text { 0,015 (KLH, No } 51 \text { Tahun } \\
2004 \text { ) }\end{array}$ \\
\hline
\end{tabular}

Tabel 4. Hasil Analisis Korelasi Spearmean Kepadatan Mikroalga Epifit dengan Parameter Lingkungan Perairan Pulau Kabung

\begin{tabular}{|c|c|c|c|c|c|c|c|c|c|}
\hline \multirow{5}{*}{ 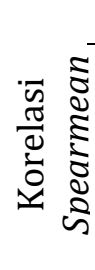 } & Suhu & DO & $\mathrm{pH}$ & Sal & Kond & Kedalaman & Arus & Nitrat & Fosfat \\
\hline & 1.000 & 1.000 & & - & - & .500 & 1.000 & 1.000 & .500 \\
\hline & ** & ** & & 1000 & 1.000 & & $* *$ & ** & \\
\hline & & & & & & .667 & . & . & .667 \\
\hline & 3 & 3 & 3 & 3 & 3 & 3 & 3 & 3 & 3 \\
\hline
\end{tabular}

salinitas dan konduktivitas maka semakin rendah nilai kepadatan. Mikroalga epifit tidak akan bertahan jika konduktivitas di perairan terlalu tinggi (Novia et al., 2016). Parameter lingkungan seperti kedalaman, $\mathrm{pH}$ dan fosfat cenderung tidak menunjukkan korelasi terhadap kepadatan mikroalga epifit.

\section{Kesimpulan}

Kesimpulan dari hasil penelitian ini adalah struktur komunitas mikroalga epifit yang ditemukan pada Padina dan Caulerpa di perairan Pulau Kabung terdiri dari 5 divisi, 7 kelas, 45 ordo, 62 famili dan 76 genus. Kepadatan mikroalga epifit tertinggi diperoleh pada Padina di stasiun III sebesar 4873 ind/5g, sedangkan kepadatan mikroalga epifit terendah diperoleh pada Caulerpa sebesar 2653 ind/5 g di stasiun I. Nilai indeks keanekaragaman $\left(\mathrm{H}^{\prime}\right)$ berkisar antara $(3,58$ 3,71 ) yang menunjukkan bahwa tingginya keanekaragaman jenis mikroalga epifit, indeks keseragaman (E) $(0,84-0,89)$ menunjukkan keseragaaman yang sama, indeks dominansi (C) $(0,03-0,04)$ menunjukkan tidak ada jenis mikroalga epifit yang mendominansi dan indeks similaritas Sorensen menunjukkan adanya kemiripan jenis mikroalga pada setiap stasiun. Parameter lingkungan yang berkorelasi dengan kepadatan mikroalga epifit adalah suhu, DO, salinitas, konduktivitas, arus dan nitrat dengan nilai 1 sampai - 1 , sedangkan kedalaman, fosfat dan $\mathrm{pH}$ cenderung tidak menunjukkan korelasi terhadap kepadatan mikroalga epifit.

\section{Daftar Pustaka}

Al-Harbi, S. M. 2017a. Epiphytic Microalgal Dynamics and Species Composition on Brown Seaweeds (Phaeophyceae) on the Northern Coast of Jeddah, Saudi Arabia. 
Jurnal Laut Khatulistiwa, Vol. 4. No. 1 (Febuari, 2021), Hal. 29-39.

Journal Oceanography and Marine Research. 5(1): 1-9

Al-Harbi, S. M. 2017b. Epipihytic Microalgal Species Composition and Dynamics on Host Green Seaweeds (Ulvaphyceae) on the Northern Coast of Jeddah, Saudi Arabia. Journal Environment and Ecology Research. 5(3): 212-119.

Aprianti, N.S., B. Sulardiono, and M. Nitisupardjo. 2015. Kajian tentang Fitoplankton yang Berpotensi sebagai HABs (Harmful Algal Blooms) di Muara Sungai Plumbon Semarang, Diponegoro. Journal of Maquares. 4(3):132-138.

Arinardi, O.H., A.B. Sutomo, A.S. Yusuf, Trimaningsih, E. Asnaryanti, dan S.H. Riyono. 1997. Kisaran dan Kelimpahan Komposisi Plankton Predominan di Perairan Kawasan Timur Indonesia. Pusat Penelitian dan Pengembangan Oceanografi. LIPI, Jakarta.

Awal, J., T. Hammado, dan P.T. Eka. 2014. Identifikasi Alga Sebagai Bioindikator Tingkat Pencemaran Di Sungai Lamasi Kabupaten Luwu. Journal Dinamika. 5(2): 21-34.

Badan Pusat Statistik Provinsi Kalimantan Barat. 2010. Kalimantan Barat Dalam Angka. Pontianak.

Barus, T.A. 2002. Pengantar Limnologi. USU Press, Medan.

Barokah, G.R., A.K. Putri, and Gunawan. 2016. Kelimpahan Fitoplankton Penyebab HAB (Harmful Alga Bloom) di Perairan Teluk Lampung pada Musim Barat dan Timur.

Dhaktie, P.A., A.D. Deshpande, B.B. Gogte, and B.W. Phate. 2011. Testing Ecofriendly Detergent Powder and Liquid Detergent. Journal International of Research in Pharmacy and Chemistry. 1(3): 22312781.

Din-El, S., G.N. Shaltout, A.N. Shaltout, M.Z. Nassar, dan A. Soliman. 2015. Ecological Studies of Epiphytic Microalgae and Epiphytic Zooplankton on Seaweed of the Eastern Harbor Alexandria Egypt. Journal Enviromental Science. 11(6): 450-473.

Eaton, A.D., Clesceri, S. Lenore, E. Rice, Greenburg, E. Arnold, Franson, and A.H. Marry. 1995. Standart Methods for the Eximination of Water and Wastwater. Baltimore, American Public Health Association. Maryland.
Hadiyanto, dan M. Azim. 2012. Mikroalga Sumber Pangan dan Energi Masa Depan. UPT UNDIP Press, Semarang.

Handayani, T. and A. Kadi. 2007. Keanekaragaman dan Biomassa Alga di Perairan Minahasa Utara. Sulawesi Utara, Pusat Penelitian Oseanografi. LIPI. Jakarta.

Hendrawati, N., Salwiyah, dan Haslianti. 2018. Komposisi dan Kepadatan Epifit yang Menempel pada Batu di Kawasan Air Terjun Moramo Kabupaten Konawe Selatan. Journal Manajemen Sumber Daya Perairan. 3(3): 189-197.

Herlina, N. Idiawati, dan I. Safitri. 2018. Diversitas Mikroalga Epifit Berasosiasi pada Daun Lamun Thalassia hemprichii di Pulau Lemukutan Kalimantan Barat. Journal Laut Khatulistiwa. 1(2): 1-8.

Ismail, J.S. 2016. Perifiton pada Daun Lamun Thalassia hemprichii dan Cymodocea Rotundata di Kampung Kampe Desa Malang Rapat Tanjung Pinang. Skripsi. Jurusan Ilmu Kelautan. Fakultas Ilmu Kelautan dan Perikanan. Universitas Maritim Raja Ali Haji.

Kementerian Lingkungan Hidup. 2004. Keputusan Kantor Menteri Negara Lingkungan Hidup No. Kep 51/MENLH/I/2004. Tentang Pedoman Penetapan Baku Mutu Lingkungan.

Kawaroe, M., T. Partono, A. Sunuddin, D.W. Sari, dan D. Agustine. 2010. Mikroalga Potensi dan Pemanfaatannya Untuk Produksi Bio Bahan Bakar. IPB Press. Bogor.

Krebs, C.J. 1989. Ecology Methodology. The Experimental Analysis of Distribution and Abundance. Harper and Row Publishers. New York.

Lestari, R.D.A., Apriansyah and I. Safitri. 2020. Struktur Komunitas Mikroalga Epifit Pada Padina sp. di Perairan Desa Sepempang Kabupaten Natuna. Journal Laut Khatulistiwa. 3(2): 1-8.

Luthfiandra, S., N. Irvina, dan Efriyeldi. 2018. Hubungan Konsentrasi Nitrat Fosfat dan Silikat Dengan Kelimpahan Diatom Planktonik Di Perairan Teluk Buo Kecamatan Bungus Teluk Kabung Kota Padang, Sumatera Barat.

Magurran, A.E. 1988. Ecologycal Diversity and Its Measurement. Chapmant And Hall. Boundary Row. London. 
Marianingsih, P., E. Amelia, dan T. Suroto. 2013. Invertarisasi dan Identifikasi Makroalga di Perairan Pulau Untung Jawa. Journal Semirata. 2019-225.

Mara, D, and S. Craincross. 1994. Pemanfaatan Air Limbah dan Ekskreta Patokan untuk Perlindungan Kesehatan Masyarakat, Bandung, Universitas Udayana dan ITB.

Merizawati. 2008. Analisis Sinar Merah, Hijau dan Biru (RGB) Untuk Mengukur Kelimpahan Fitoplankton (Chlorella sp.). Skripsi. Fakultas Perikanan dan Ilmu Kelautan. Bogor: Institut Pertanian Bogor.

Nitajohan, Y.P. 2008. Kelimpahan Dinoflagelata Epibentik pada Lamun Enhalus acoroides (L.F) Royle Dalam Kaitannya Dengan Parameter FisikaKimia di Ekosistem Lamun pulau Pari, kepulauan Seribu Jakarta. Skripsi. Bogor: Institut Pertanian Bogor. Fakultas Perikanan dan Ilmu kelautan.

Novia, R., Adnan and I.R. Ritonga. 2016. Hubungan Parameter Fisika-Kimia Perairan dengan Kelimpahan Plankton di Samudera Hindia Bagian Barat Daya. Depik. 5(2): 67-76.

Nurdiansyah, S.I., R.S. Tri, dan Junaidi. 2010. Struktur Komunitas Alga Perifiton Pada Lamun Enhalus acoroides Di Perairan Pulau Penata Besar Kabupaten Bengkayang. Skripsi. Pontianak.

Odum, E.P.1993. Dasar Dasar Ekologi. Gajah Mada Univ Press. Yogyakarta.

Pello, F.S., E.M. Adwilaga, N.V. Huliselan, and A. Damar. 2014. Effect of Seasonal on Nutrient Load Input the Inner Ambon Bay. Bumi Lestari. 14(1): 63-73.

Pitipaldi, K., A. Bakhtiar, dan H. Suliantoro. 2017. Analisis Korelasi Spearman SNI ISO Standar Sistem Manajemen Kualitas Terhadap Hak Kekayaan Industrial di Indonesia. Journal Departemen Teknik Industri. UNDIP.

Pulukadang, I, R.C. Keppel, and G.S. Gerung. 2013. A Study On Bioecology of Macroalgae Genus Caulerpa in Northern Minahasa Waters, North Sulawesi Province. Aquatic Science and Management. 1(1): 26-31.

Putri, F.D.M, E. Widyastuti, dan Christiani. 2014. Hubungan Perbandingan Total Nitrogen dan total Fosfor Dengan
Kelimpahan Chrysophyta di Perairan Waduk Panglima Besar Soedirman, Banjarnegara. Journal Scripta Biologica., 1(1): 96-101.

Safitri, M, and M.R. Putri. 2013. Kondisi Keasaman $(\mathrm{pH})$ Laut Indonesia. Fakultas Ilmu dan Teknologi Kebumian. ITB. Bandung.

Tarigas, M.T., Apriansyah, I. Safitri. 2020. Struktur Komunitas Mikroalga Epifit Berasosiasi Pada Sargassum sp.di Perairan Desa Sepempang Kabupaten Natuna. Journal Laut Khatulistiwa., 3(2): 9-16.

Utama, A.P., S. Nirwani, and E. Hadi. 2019. Komposisi Perifiton Pada Daun Lamun Enhalus acoroides, Royle 1839 (Angiosperms: Hydrocharitaceae) dan Thalassia hemprichii, Ascherson 1871 (Angiosperms: Hydrocharitaceae) di Perairan Teluk Awur Jepara. Journal of Marine Research. 8 (4): 340-345.

Vinneras, B. 2006. Faecal Separation and Urine Diversion for Nutrient Management of Household Biodegradable Waste and Wastewater. Tesis. Uppsala: Swedish University of Agricultural Sciences.

Wai, M.K. and Soe-Htun. 2013. Studies on the Morphlogy and Distribution of Padina boryana Thivy (Dictyotales, Phaeophyta) from Myanmar. Journal Universites Research. 1(4): 2-15.

Washington, H.G. 1984. Diversity Biotik and Similarity Indices: A riview with special relevance to aquatic ecosystem. Journal Int. Assoc. Wat. Pollut. Res. Contrl., 118:653-694.

Win, N.N., T. Hayunda, S.G.A. Draisma, P.E. Lim, S.M. Phang, and H. Kawai. 2013. Taxonomy of the Genus Padina (Dictyotsles, Phaeophyceae) Based on Morphological and Molecular Envidences, With Key to Species Identification, Taxonomy of Southeast Asian Seaweeds II: Phang and Lim (eds): 119-174.

Yusuf, M., Muliadi, dan M. Sukal. 2018. Komposisi dan Struktur Komunitas Fitoplankton di Estuari Sungai Mempawah, Kalimantan Barat: Skripsi.

Zhou, H., C. Jiang, L. Zhu, X. Wang, X. Hu, J. Cheng, and M. Xie. 2011. Impact of Pond and Fence Aquaculture on Resevoir 
Jurnal Laut Khatulistiwa, Vol. 4. No. 1 (Febuari, 2021), Hal. 29-39.

Environment. Water Science and

Engineering. 4(1): 92-100. 